\author{
Małgorzata Janiak \\ ORCID 0000-0003-4099-0224 \\ Uniwersytet Łódzki \\ Instytut Geografii Miast i Turyzmu \\ malgorzata.janiak@geo.uni.lodz.pl \\ Monika Kozłowska-Adamczak \\ ORCID 0000-0002-4465-0043 \\ Uniwersytet Kazimierza Wielkiego w Bydgoszczy \\ Instytut Geografii \\ monika.kozlowska@ukw.edu.pl
}

\title{
WALORYZACJA NAJPOPULARNIEJSZYCH PORTALI REZERWACYJNYCH $Z$ PUNKTU WIDZENIA UŻYTECZNOŚCI KONSUMENCKIEJ I NAUKOWEJ
}

\begin{abstract}
Abstrakt: Przemysł hotelarski zalicza się do fundamentalnych usług związanych z obsługą ruchu turystycznego. Biorąc pod uwagę dynamiczny rozwój Internetu i wzrastającą liczbę jego użytkowników, naturalne jest prezentowanie i sprzedaż oferty (m.in. przez hotelarzy) za pośrednictwem tego właśnie medium. Współcześnie szczególne znaczenie w hotelarstwie ma szerokie zastosowanie globalnych i międzynarodowych portali rezerwacyjnych, stanowiących nowoczesny kanał dystrybucji usług i produktów turystycznych na cały świat. Celem autorek artykułu jest próba oceny użyteczności i funkcjonalności czterech najbardziej znanych na polskim rynku hotelowych portali rezerwacyjnych (booking.com, hrs.com, hotels.com i hotel.info) z punktu widzenia konsumenta (turysty), a następnie określenie przydatności tego źródła danych do badań naukowych przy wykorzystaniu metody waloryzacji danych dotyczących hoteli zlokalizowanych w pięciu polskich metropoliach (Warszawie, Krakowie, Łodzi, Wrocławiu i Poznaniu).
\end{abstract}

Słowa kluczowe: e-marketing, użyteczność hotelowych portali rezerwacyjnych, waloryzacja.

\section{WPROWADZENIE}

Stale zwiększające się oczekiwania i wymagania klientów, a także rosnąca konkurencyjność wpływają na poszukiwanie przez hotelarzy najwydajniejszych i najskuteczniejszych metod utrzymania się na rynku oraz umocnienia na nim swojej pozycji (WITKOWSKI 2007). Wielu badaczy zwraca uwagę na specyfikę sektora turystycznego, podkreślając, że wymaga on dostarczania informacji do wielu odbiorców jednocześnie (SHELDON 1997, WERTHNER i KLEIN 1999). Zgodnie z opinią R. LAWA (2009) wykorzystanie technologii informacyjnej ma decydujący wpływ na sektor hotelowy, w szczególności na sposób zarządzania firmą. $Z$ tego względu od około 1990 r. mówi się o marketingu internetowym (zwanym e-marketingiem lub e-commerce). Początkowo były to proste strony internetowe, oparte przede wszystkim na tekście, na których oferowano produkty lub informacje. $Z$ biegiem czasu i rozwojem informatyki strony te ewoluowały w coś więcej niż tylko narzędzie do sprzedaży danych, np. pozwalają one po- zyskiwać informacje od gości i łączą punkty komunikacji z gościem (BONICKA, ANTONOWICZ 2018). Już w 2004 r. gałąź gospodarki, jaką jest turystyka, została uznana za najlepszą pod względem dokonanych transakcji on-line (WERTHNER, RICCI 2004). C.H. MARCUSSEN (2008) stwierdza w swojej publikacji, że w dziale turystyki to właśnie rezerwacja hoteli on-line stanowi drugi co do wielkości (po rezerwacji biletów lotniczych) przedmiot sprzedaży. Dzieje się tak dlatego, że współczesnemu, kompleksowemu rozwojowi branży hotelarskiej już od lat 80. XX w. towarzyszy m.in. ekspansja wyspecjalizowanych globalnych systemów rezerwacji (np. Amadeus, WorldSpan, Galileo, Sabre), a także dostępnych dla każdego konsumenta międzynarodowych systemów hotelarskich (ANTONOWICZ 2018) czy internetowych agencji podróży (on-line travel agency), które odgrywają rolę pośredników (STANGL, INVERSINI, SCHEGG 2016, DROZDOWSKA, DUDA-SEIFERT 2016). 
M. BRANNBACK (1997) uważa, że znaczenie informatyki w procesie docierania do klientów systematycznie wzrasta, zwłaszcza w związku z oferowaniem produktów i infrastruktury $\mathrm{w}$ formie elektronicznej. Technologia informacyjna nie pełni już tylko funkcji wspierającej, ale stanowi główny czynnik decydujący o pozycji firmy na rynku. $Z$ tego powodu hotelarze muszą zaznaczać swoją obecność w tym właśnie medium oraz wykorzystywać postęp techniczny w całym procesie produkcji - od kształtowania oferty po jej dystrybucję i reklamę (BŁASZCZUK, WITKOWSKI 2006). Mniej więcej od 2001 r. sprzedaż on-line stała się alternatywą dla tradycyjnych kanałów dystrybucji i dość szybko zaczęto wykorzystywać ją w usługach turystycznych (DROZDOWSKA, DUDA-SEIFERT 2016). Z tego powodu od kilku lat widoczny jest znaczny wzrost sprzedaży usług hotelowych $\mathrm{z}$ wykorzystaniem pośredników, takich jak m.in. portale rezerwacyjne, a tym samym coraz częściej pomija się tradycyjną sprzedaż bezpośrednią (ANTONOWICZ 2018). W opinii T. EsCOBARA-RODRÍGUEZA i E. CARVAJAL-TRUJILLO (2013) narzędzia on-line stanowią wygodną formę poznawania produktów oferowanych przez daną firmę, co może przełożyć się na zwiększony zysk ze sprzedaży. Decydując się na wykorzystanie portali (pełniących funkcję agenta), przedsiębiorca może liczyć na przykuwające uwagę konsumenta „opakowanie marketingowe”, pozyskanie gości, a nawet przygotowanie oferty sprzedaży. Zdaniem W. ANTONOWICZA (2018) wykorzystanie znanych pośredników może zaś dać właścicielowi przedsiębiorstwa przewagę w uzyskaniu dostępu do pożądanych rynków zbytu i segmentów klientów oraz może zapewnić dobrą widoczność obiektu w Internecie (tzw. efekt billboardu). Z punktu widzenia systemu gospodarczego głównym zadaniem pośredników jest przekształcenie oferty produktów wytwarzanych przez producentów na asortyment poszukiwany przez konsumentów. Touroperatorzy proponują skromne pakiety produktów w dużych ilościach, a konsumenci oczekują szerokiego wachlarza towarów, oferowanych w małych ilościach. Aby sprostać takim oczekiwaniom klientów, pośrednicy (w tym przypadku portale rezerwacyjne) kupują dużo artykułów od wielu producentów, a następnie tworzą z nich małe pakiety. Poprzez takie działanie pośrednicy pełnią ważną funkcję w dopasowywaniu podaży i popytu, a także znacząco redukują ilość pracy, która musiałaby zostać wykonana przez producenta i przez konsumenta, zanim dokonano by sprzedaży i zakupu towaru (KOTLER 2002).

E-marketing wykorzystywany jest do realizacji głównego celu przedsiębiorstwa (tj. maksymalizacji zysków), który powinien zakładać rozpoznawanie potrzeb klientów i sprawianie, że oferowany produkt będzie przynosił im pełną satysfakcję. Takie działania wpisują się sposób „patrzenia na działalność gospo- darczą z pozycji odbiorcy" (PRZYBYLAK 2005, s. 257). Jest to dość trudne zadanie, gdyż osób korzystających z Internetu szybko przybywa. Szacunkowo na świecie jest ich ponad $3 \mathrm{mld}$, a w samej Polsce - około $27 \mathrm{mln}$. Statystyczny użytkownik, rezerwując hotel, przegląda średnio 17 różnych stron internetowych, a przed ostatecznym zrobieniem rezerwacji przeznacza zwykle kilka tygodni na poszukiwania. Jednak gdy zapadnie już decyzja o wyjeździe, rezerwacja dokonywana jest szybko i sprawnie. Podróżni rozpoczynają poszukiwania obiektów noclegowych od przeglądania Internetu, ale nie ograniczają się już tylko do korzystania z wyszukiwarki typu Google (http:/ / www.e-hotelarz.pl/mht $/$ ?p=29196). W związku z tym przedstawienie firmy za pomocą marketingu internetowego opiera się głównie na modelu strukturalnym i funkcjonalnym. Serwis internetowy może przyjąć układ portalowy (wielotematyczny) lub wortalowy (jednotematyczny), czyli zorientowany na publikowanie jak największej ilości informacji. W przypadku portali rezerwacyjnych mówimy o układzie wortalowym, gdzie bardzo duża powierzchnia została zagospodarowana na rotacyjną ekspozycję treści (ofert różnych obiektów noclegowych), która zmienia się wraz z upływem czasu i jest prezentowana $\mathrm{w}$ formie krótkich migawek treści, znajdujących się w jednej lub dwóch kolumnach na stronie startowej (https:/ / poradnikprzedsiebiorcy.pl/-market ing-internetowy0/2).

Rynek rezerwacji internetowych w Polsce zaczął się rozwijać na przełomie XX i XXI wieku, a dynamiczny wzrost jego znaczenia odnotowano w połowie ubiegłej dekady. Jednym z pierwszych polskich portali rezerwacyjnych był StayPoland.com, który z czasem stracił pozycję lidera na rzecz witryny OdkryjPolske.pl, należącej do biura turystycznego Polish Travel Quo Vadis. Obecnie, według części hotelarzy, na czele ryn$\mathrm{ku}$ polskich portali rezerwacyjnych stoi serwis hotele.pl, którego właścicielem jest firma NetMedia. Dopiero gdy w drugiej połowie ubiegłej dekady przemysł hotelarski w Polsce zaczął się intensywniej rozwijać, krajowym rynkiem zainteresowali się przedstawiciele międzynarodowych portali rezerwacyjnych. Wśród nich pozycję lidera zajął Booking.com (firma założona w 1996 r. w Amsterdamie), który jako pierwszy wprowadził polskojęzyczną wersję swojego serwisu, a dziś jest najbardziej rozpoznawalnym portalem tego typu w Polsce (https:/ / www.e-hotelarz.pl/mht/ $? \mathrm{p}=14002)$

\section{CELE I METODY BADAŃ}

Zakres merytoryczny artykułu jest określony przez pojęcie portali rezerwacyjnych, odnoszące się do systemów informacyjnych przygotowanych do przetwa- 
rzania, selekcjonowania i integracji dostarczonych na wejściu danych uzyskanych $\mathrm{z}$ różnych źródeł (tj. stron internetowych obiektów hotelowych), aby na wyjściu otrzymać informacje przydatne do realizacji celu, w jakim dany system został stworzony (PIĄDŁOWSKI 2006).

W związku z powyższym zamierzeniem autorek artykułu jest próba oceny użyteczności hotelowych portali rezerwacyjnych $z$ punktu widzenia turysty (tj. osoby poszukującej przydatnych informacji nt. bazy noclegowej przed udaniem się $\mathrm{w}$ podróż) oraz badacza (zbierającego dane do analiz naukowych). Rozważania opierają się na informacjach pozyskanych podczas kwerend internetowych przeprowadzonych w okresie od kwietnia do maja 2017 r. w objętych badaniem portalach rezerwacyjnych na przykładzie danych dotyczących bazy hotelowej pięciu największych polskich miast o randzie metropolii (tj. Warszawy, Krakowa, Łodzi, Poznania i Wrocławia). Autorki postanowiły ograniczyć zakres badań do hoteli ze względu na to, że są one najważniejszą grupą w bazie noclegowej, co wiąże się z liczebnością tego rodzaju podmiotów oraz z tym, że hotele stanowią najstarszą i najbardziej klasyczną reprezentację obiektów noclegowych. Dodatkowo cechą wyróżniającą hotele jest szeroki wachlarz oferowanych usług, które wykraczają poza sprzedaż noclegu zarówno pod względem ilościowym, jak i jakościowym (HYSKI, BEDNARZAK 2012).

Cała procedura badawcza została podzielona na trzy części. Najpierw dokonano wyboru konkretnych portali rezerwacyjnych, co poprzedzono sondażem diagnostycznym, przeprowadzonym wśród konsumentów rynku turystycznego (26 studentów kierunku turystyka i rekreacja z Bydgoszczy), którzy przed wyruszeniem w podróże turystyczne z chęcią korzystają ze zdobyczy nowych technologii. Wskazania respondentów stały się podstawą do objęcia badaniem czterech serwisów rezerwacyjnych, wykorzystywanych w Polsce (booking.com, hrs.com, hotels.com i hotel.info), które docelowo analizowano w odniesieniu do wybranych pięciu krajowych metropolii (tj. dużych miast, w których według stanu na 2017 r. mieszkało minimum 500 tys. osób). Na drugim etapie badania, przy udziale tej samej grupy respondentów, dokonano wyboru neutralnych kryteriów, aby następnie na ich podstawie przeprowadzić próbę obiektywnej i syntetycznej oceny portali pod względem szeroko pojętej użyteczności. W tym celu wykorzystano metodę bonitacji punktowej, stosowaną z powodzeniem w licznych opracowaniach geograficznych (np. MATCZAK 1986, WOJCIECHOWSKA 2003, RUNGE 2006). Zgodnie z przyjętymi przez autorki skalami ${ }^{1}$ każdy z portali rezerwacyjnych został oceniony poprzez przyznanie odpowiedniej liczby punktów według opracowanych kryteriów. Waloryzacji poddano 30 kryteriów podzielonych na trzy podstawowe grupy tematyczne (tab. 1):
- pierwsze wrażenie, jakie wywiera portal;

- ogólne funkcje portalu;

- informacje praktyczne dla użytkowników portalu.

Ostatecznie dzięki temu możliwe było obliczenie współczynnika waloryzacji ${ }^{2}$ oraz wyznaczenie przedziałów klasowych (co 25\%), przyjmując, że portale, które mieszczą się $\mathrm{w}$ przedziale zamykającym się w najniższych wartościach $(0-0,25)$, należy uznać za nieużyteczne, a w najwyższych $(0,76-1,00)$ - za bardzo użyteczne.

W ostatniej części zweryfikowano rzetelność i wiarygodność dostępnych danych (na zwaloryzowanych wcześniej portalach rezerwacyjnych) pod katem ich potencjalnego wykorzystania do wnioskowania naukowego. Analizie porównawczej, według przyjętych kryteriów użyteczności naukowej (zob. tab. 3), poddano więc treści zamieszczone $\mathrm{w}$ czterech portalach (booking.com, hrs.com, hotels.com i hotel.info), dotyczące obiektów hotelowych zlokalizowanych w Warszawie, Krakowie, Łodzi, Wrocławiu i Poznaniu. Na tym etapie wybrano sześć cech związanych z branżą hotelarską, które zdaniem autorek pracy są obiektywne, uniwersalne i - co najważniejsze - nadają się do wykorzystania przy analizie porównawczej portali rezerwacyjnych. Wśród nich znajdują się te kryteria, które pozwalają na porównanie zarówno wielkości, jak i struktury zasobów hotelowych, prezentowanych w wybranych portalach rezerwacyjnych (np. liczba obiektów hotelowych ogółem, liczba obiektów z sieci hotelowych, kategorie hoteli według liczby gwiazdek, liczba hoteli według przedziału cenowego).

Na szczególną uwagę zasługuje kryterium określające "lokalizację obiektu noclegowego". Należy przez to rozumieć odległość ( $w$ metrach lub kilometrach) w przestrzeni miasta, obrazującą fizyczne położenie hotelu w odniesieniu do centrum administracyjnego danej aglomeracji. Dzięki temu udało się wyznaczyć ekwidystanty. Przyjęto jednocześnie, że bufor bliskiego zasięgu do $2 \mathrm{~km}$ ( $\mathrm{z}$ hotelu do centrum) turysta może swobodnie pokonać piechotą, średniego zasięgu (2,1-5 km) - w zależności od upodobań pieszo lub poruszając się komunikacją miejską, a w przypadku dalekiego zasięgu (powyżej $5 \mathrm{~km}$ ) musi skorzystać $\mathrm{z}$ transportu zbiorowego lub indywidualnego. Ostatnią interesującą cechą jest „rozpiętość między maksymalną a minimalną ceną ofert hoteli". Pozwala ona na prześledzenie i określenie zróżnicowania wysokości cen w każdym analizowanym portalu rezerwacyjnym według przyjętego do badania przedziału czasowego, np. w konkretnym dniu lub w innym okresie (np. podczas weekendu). Dzięki temu istnieje możliwość śledzenia aktualnych zmian cenowych ofert hotelowych na rynku aglomeracji wybranych do badania. 
Tab. 1. Kryteria oceny (zasady bonitacji punktowej) wybranych elementów mających największe znaczenie dla określenia obiektywnej użyteczności czterech portali rezerwacyjnych obiektów hotelowych w Polsce

Kryteria oceny

Skala punktowa (liczba pkt.)

\begin{tabular}{l|l|l|l|l|}
0 & 1 & 2 & 3 & 4 \\
\hline
\end{tabular}

Pierwsze wrażenie, jakie wywiera portal

Estetyka portalu

\begin{tabular}{|l|l|l|l|l|} 
bardzo źle & źle & średnio & dobrze & bardzo dobrze \\
\hline
\end{tabular}

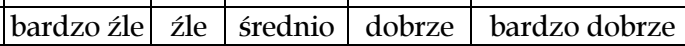

Ogólna czytelność portalu

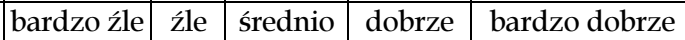

Występowanie łatwego w obsłudze menu (intuicyjna obsługa portalu) Ogólne funkcje portalu

Zakres ogólnych warunków handlowych \begin{tabular}{|c|c|c|c|c|}
\hline bardzo źle & źle & średnio & dobrze & bardzo dobrze \\
\hline
\end{tabular} Gwarancja ceny ze zwrotem pieniędzy

Elastyczność warunków rezerwacji

Zależność między ceną i charakterem obiektu a typem wyjazdu (biznesowym lub wypoczynkowym)

Gwarancja ochrony danych osobowych i bezpieczeństwo połączenia internetowego

Możliwość założenia bezpłatnego konta w portalu

Możliwość zarządzania rezerwacją on-line

Możliwość zainstalowania bezpłatnej aplikacji mobilnej

Powiązanie portalu z mediami społecznościowymi

(np. Facebook, Twitter itp.)

\begin{tabular}{|l|l|l|l|l|l}
\hline Zakres dodatkowych usług dostępnych za pośrednictwem portalu (np. zakup & bardzo źle & źle & średnio & dobrze & bardzo dobrze
\end{tabular} biletu lotniczego lub kolejowego, wynajem samochodu, wynajem taksówki itd.)

Pakiety lojalnościowe

Możliwość selekcji różnego rodzaju obiektów noclegowych

Pozycjonowanie obiektów, w których oferowane jest zakwaterowanie według kryteriów podanych przez klienta

Wsparcie w zakresie e-marketingu dla hotelarzy

Oferty skierowane specjalnie dla grup

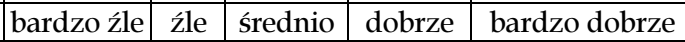

\begin{tabular}{|c|c|c|c|c} 
brak & jest & $\mathrm{x}$ & $\mathrm{x}$ & $\mathrm{x}$ \\
\hline
\end{tabular}

\begin{tabular}{cc|c|c|c} 
brak & jest & $\mathrm{x}$ & $\mathrm{x}$ & $\mathrm{x}$ \\
\hline brak & jest & $\mathrm{x}$ & $\mathrm{x}$ & $\mathrm{x}$
\end{tabular}

brak

\begin{tabular}{c|c|c|c|c}
\hline brak & jest & $\mathrm{x}$ & $\mathrm{x}$ & $\mathrm{x}$
\end{tabular}

brak

brak jest

brak

brak

jest

$\mathrm{x}$

t $x$

\begin{tabular}{c|c|c}
$x$ & $x$ \\
\hline
\end{tabular}

$\mathrm{x}$

$\mathrm{x}$

$x$

Informacje praktyczne dla użytkowników portalu

Brak opłat za dokonanie rezerwacji zakwaterowania za pośrednictwem portalu

Możliwość bezpłatnego anulowania rezerwacji

Możliwość skorzystania z ofert first minute

Możliwość samodzielnego wyboru wersji językowej w portalu

Możliwość samodzielnego wyboru waluty

Możliwość wyboru daty pobytu w obiekcie noclegowym

(nawet z kilkumiesięcznym wyprzedzeniem)

Dostęp do mapy z lokalizacją obiektów noclegowych

Możliwość korzystania z różnych filtrów informacji

Sortowanie obiektów według ceny pokoju za jedną noc

Sortowanie obiektów według liczby gwiazdek przyznanych przez portal

Możliwość śledzenia opinii i sugestii innych użytkowników portalu nt. konkretnych obiektów

Możliwość dodania własnej oceny po zalogowaniu się na konto

Informacja o liczbie aktualnie dostępnych pokojów w danym obiekcie noclegowym

Informacja o liczbie osób aktualnie zainteresowanych konkretnym obiektem noclegowym

Wyświetlanie alertu o zarezerwowanym pokoju w konkretnym obiekcie noclegowym $w$ danej jednostce czasu (np. w ciągu kilku godzin lub dni)

Poziom prezentowanych informacji dodatkowych nt. obiektów noclegowych

Ranking najlepszych lub najpopularniejszych obiektów noclegowych w Polsce i na świecie

Całodobowy serwis telefoniczny dla użytkowników

Odpowiedź na najczęściej zadawane pytania w portalu

\begin{tabular}{|c|c|c|c|c|}
\hline brak & jest & $x$ & $x$ & $x$ \\
\hline brak & jest & $x$ & $x$ & $x$ \\
\hline brak & jest & $x$ & $x$ & $x$ \\
\hline bardzo źle & źle & średnio & dobrze & bardzo dobrze \\
\hline bardzo źle & źle & średnio & dobrze & bardzo dobrze \\
\hline brak & jest & $x$ & $x$ & $x$ \\
\hline brak & jest & $x$ & $x$ & $x$ \\
\hline bardzo źle & źle & średnio & dobrze & bardzo dobrze \\
\hline brak & jest & $\mathrm{x}$ & $\mathrm{x}$ & $\mathrm{x}$ \\
\hline brak & jest & $\mathrm{x}$ & $\mathrm{x}$ & $\mathrm{x}$ \\
\hline brak & jest & $\mathrm{x}$ & $\mathrm{x}$ & $\mathrm{x}$ \\
\hline brak & jest & $\mathrm{x}$ & $\mathrm{x}$ & $\mathrm{x}$ \\
\hline brak & jest & $\mathrm{x}$ & $\mathrm{x}$ & $\mathrm{x}$ \\
\hline brak & jest & $\mathrm{x}$ & $\mathrm{x}$ & $\mathrm{x}$ \\
\hline brak & jest & $\mathrm{x}$ & $\mathrm{x}$ & $\mathrm{x}$ \\
\hline bardzo źle & źle & średnio & dobrze & bardzo dobrze \\
\hline brak & jest & $\mathrm{x}$ & $\mathrm{x}$ & $\mathrm{x}$ \\
\hline brak & jest & $\mathrm{x}$ & $\mathrm{x}$ & $\mathrm{x}$ \\
\hline brak & jest & $\mathrm{x}$ & $\mathrm{x}$ & $\mathrm{x}$ \\
\hline & & & & \\
\hline
\end{tabular}

Objaśnienia: $\mathrm{x}$ - brak oceny przy analizie danego kryterium.

Źródło: opracowanie własne. 


\section{OCENA UŻYTECZNOŚCI HOTELOWYCH SERWISÓW REZERWACYJNYCH - SYNTEZA}

W ostatnich latach wielu autorów coraz chętniej zajmuje się szeroko pojętą problematyką zróżnicowanych serwisów, witryn i portali internetowych, analizując ich przydatność do różnych celów. Część badań dotyczy przykładowo użyteczności publicznych portali miejskich dla rozwoju turystyki (BAŃSKI 2006, GUZIK 2006, PRAŁAT 2011, NOWAKOWSKI 2012), inne prowadzone są, aby określić, czy treści zawarte $\mathrm{w}$ turystycznych portalach internetowych są na tyle rzetelne, by można było wykorzystać je do badań marketingowych (DROZDOWSKA, DUDA-SEIFERT 2016). W związku z tym użyteczność serwisu (ang. web usability), a tym samym każdego portalu i witryny internetowej, to zakres, w jakim serwis może być wykorzystany przez konkretnych użytkowników do osiągnięcia wyznaczonych celów, zgodnych z regułami skuteczności, efektywności i satysfakcji w określonym kontekście użycia (NOWAKOWSKI 2012). W tym ujęciu aspekty użyteczności hotelowych portali rezerwacyjnych wpływają bezpośrednio na komfort korzystania z nich oraz łatwość dostępu do poszukiwanych przez użytkowników informacji. Dotyczy to nie tylko konsumentów (turystów), ale także badaczy szukających ciekawych źródeł danych do analiz naukowych. Dzieje się tak, gdyż w portalach, udostępniających klientom usługi, prezentowane są jednocześnie informacje otrzymywane od dostawców (t). gestorów bazy noclegowej). Dostawcy zaś zobowiązani są do uaktualniania za pośrednictwem extranetu (tj. wewnętrznej sieci internetowej $\mathrm{w}$ ramach portalu) wszystkich cen, dostępności oraz innych danych pojawiających się na poszczególnych platformach (https://www.booking. $\mathrm{com} /$ ).

Wyniki przeprowadzonego na początku opracowania sondażu diagnostycznego pokazały, że respondenci najczęściej (w ok. 80\%) wymieniali dwa portale rezerwacyjne istniejące na polskim rynku turystycznym. Jak można domniemać, część wskazań wynika $\mathrm{z}$ zakrojonego na szeroką skalę e-marketingu, ponieważ od kilku lat (nie tylko w Internecie, ale także w TV) pojawiają się reklamy tych portali. Jednym z nich jest niemiecka firma HRS z Kolonii (właściciel hrs.com), która została założona w 1972 r. Początkowo zajmowała się pośrednictwem $\mathrm{w}$ wynajmowaniu pokoi hotelowych osobom podróżującym służbowo i przedsiębiorstwom. Obecnie firma HRS to jedyny dostawca usług noclegowych, który integruje ofertę hoteli ze wszystkimi powszechnie używanymi globalnymi systemami rezerwacyjnymi (Global Distribution System - GDS), takimi jak: Amadeus, Sabre, Worldspan, Apollo, Galileo, Abacus i TravelSky. Dziś jest największym na świecie dostawcą usług hotelowych $\mathrm{w}$ odniesieniu do liczby hoteli $\mathrm{i}$ oferowanych $\mathrm{w}$ nich pokoi (https://www.hrs.com/). Drugim najpopularniejszym wśród respondentów portalem rezerwacyjnym okazał się holenderski booking.com - spółka należąca dziś do Booking Holdings Inc. (NASDAQ: BKNG) będącego jednym $\mathrm{z}$ największych przedsiębiorstw marketingu internetowego na świecie. Dzięki temu portal specjalizuje się nie tylko $\mathrm{w}$ rezerwacjach zakwaterowania, ale umożliwia zakup biletów lotniczych czy wynajmu samochodów on-line (https:// www.booking.com/). Respondenci wymieniali również portal rezerwacyjny hotels.com z główną siedzibą w Dallas (stan Texas, USA) oraz niemiecki hotel.info, należący do spółki Hotel.de z Norymbergii (https:// pl.hotels.com/, https://www.hotel.info/).

Ocena użyteczności wszystkich czterech wskazanych przez respondentów portali rezerwacyjnych według przyjętych wcześniej kryteriów, podzielonych na trzy grupy tematyczne (tab. 1), obrazuje aspekty, które za M. NOWAKOWSKIM (2012, s. 45-46) można określić jako:

1) aspekt architektury dostępnych informacji (to kryteria skupione $\mathrm{w}$ I grupie waloryzacji, nazwanej „pierwsze wrażenie, jakie wywiera portal");

2) aspekt zawartości merytorycznej (grupa II danych dotyczących ogólnych funkcji portalu);

3) aspekt użyteczności (grupa III - „informacje praktyczne dla użytkowników portalu").

Tab. 2. Wyniki waloryzacji poziomu użyteczności objętych badaniem portali rezerwacyjnych - synteza

\begin{tabular}{|l|c|c|}
$\begin{array}{c}\text { Portal } \\
\text { rezerwacyjny }\end{array}$ & $\begin{array}{c}\text { Eączna liczba punktów } \\
\text { z waloryzacji, jaką } \\
\text { otrzymał portal rezer- } \\
\text { wacyjny (N) }\end{array}$ & $\begin{array}{c}\text { Wartość wskaźnika } \\
\text { waloryzacji wg wzoru } \\
\mathrm{N} / \mathrm{N}_{\max }, \text { gdzie } \\
\mathrm{N}_{\max }=67 \text { pkt. }\end{array}$ \\
\hline Booking.com & 59 & 0,88 \\
\hline Hotels.com & 55 & 0,82 \\
\hline Hrs.com & 49 & 0,73 \\
\hline Hotel.info & 47 & 0,70 \\
\hline
\end{tabular}

Źródło: opracowanie własne.

Analiza otrzymanych w ten sposób wyników waloryzacji portali (tab. 2) pokazała, że w przypadku wszystkich ocen średnia wartość współczynnika bonitacji mieści się tylko $\mathrm{w}$ dwóch przedziałach klasowych - 0,51-0,75 oraz 0,76-1,00, w związku z czym można podzielić badane portale rezerwacyjne odpowiednio na: 1) użyteczne pod względem przydatności zamieszczonych w nich danych i informacji (współczynnik 0,70 dla portalu hotel.info oraz 0,73 dla hrs.com) oraz 2) bardzo użyteczne (0,82 dla hotels.com i 0,88 dla booking.com). Stosunkowo wysoka przydatność i przejrzystość poszczególnych portali rezerwacyjnych staje 
się więc sposobem turystów na wygodne, łatwe i szybkie dotarcie do szerokiego wachlarza produktów i usług hotelarskich oraz zawierania stosownych transakcji kupna-sprzedaży on-line. Oznacza to, że $\mathrm{z}$ marketingowego punktu widzenia portale rezerwacyjne stanowią relatywnie rzetelne i praktyczne źródło informacji zwłaszcza dla konsumenta rynku (turysty), dla którego korzystanie z technologicznych rozwiązań badanych portali staje się współcześnie najlepszą i najszybszą drogą do pozyskania dostępu do usług turystycznych.

Uznając użyteczność prezentowanych na portalach rezerwacyjnych danych (ogółem), postanowiono sprawdzić, w jakim stopniu zawarte $\mathrm{w}$ nich treści, dotyczące już stricte obiektów hotelowych, zlokalizowanych w pięciu polskich metropoliach (Warszawie, Krakowie, Łodzi, Wrocławiu i Poznaniu), mogą okazać się przydatne do prowadzenia badań naukowych.

Dogłębna analiza treści dotyczących obiektów hotelarskich w każdym z miast według przyjętych kryteriów użyteczności naukowej ujawniła, że największą wada prezentowanych danych jest brak pewności co do faktycznego standardu szczególnie obiektów małych, rodzinnych lub niemarkowych (tj. niezrzeszonych w polskich lub międzynarodowych łańcuchach czy sieciach hotelowych). Ten problem dotyczy zwłaszcza wielu nisko skategoryzowanych pensjonatów, moteli, małych hoteli czy hosteli, co przekłada się na zróżnicowanie ogólnej liczby hoteli według poszczególnych kategorii. Największe różnice zauważa się szczególnie w Warszawie i Łodzi (tab. 3). Niejednokrotnie w objętych badaniem portalach rezerwacyjnych podawane są różne informacje na temat liczby gwiazdek posiadanych przez obiekt w danych miastach. Poza tym może ona nie być zgodna $z$ oficjalnymi wymogami kategoryzacji w myśl zapisów aktualnej nowelizacji Ustawy z dnia 29 sierpnia 1997 r. o ustugach hotelarskich oraz ustugach pilotów wycieczek i przewodników turystycznych (DzU 2018, poz. 650) lub z klasyfikacją GUS. Ten fakt może stanowić niewątpliwie podstawę do zarzucenia hotelarzowi wprowadzania swoich klientów w błąd. Z naukowego punktu widzenia budzi zaś wątpliwości to, czy informacje dotyczące kategoryzacji obiektów hotelowych, prezentowane na tym poziomie serwisów rezerwacyjnych (podobnie jak inne narzędzia związane z reklamą), są w pełni wiarygodne.

$\mathrm{Na}$ to samo pytanie w swoich badaniach, na przykładzie studium przypadku portalu rezerwacyjnego booking.com, w którym m.in. zamieszczone są informacje dotyczące obiektów noclegowych we Wrocławiu, próbowały odpowiedzieć M. DROZDOWSKA i M. DUDA-SEIFERT (2016). Badaczki uznały, że stopień wiarygodności danych dotyczących kategoryzacji obiektów w portalach rezerwacyjnych rośnie propor- cjonalnie do standardu obiektu hotelowego. Wynika to $\mathrm{z}$ faktu, że największa zgodność między różnymi źródłami informacji (tj. między danymi w portalu a oficjalnymi statystykami GUS oraz Ministerstwa Sportu i Turystyki - Centralnego Wykazu Obiektów Hotelarskich) panuje w przypadku hoteli mających co najmniej trzy gwiazdki. Do tego samego wniosku (na podstawie własnych analiz treści $\mathrm{z}$ czterech portali rezerwacyjnych, zawierających oferty $\mathrm{z}$ pięciu poskich metropolii) doszły autorki niniejszego artykułu.

Analiza danych wykazała, że informacje prezentowane $\mathrm{w}$ hotelarskich portalach rezerwacyjnych podlegają nieustannym zmianom nie tylko w systemie kilkutygodniowym czy dziennym, ale nawet na bieżąco. Dotyczy to wszystkich analizowanych atrybutów (tab. 3). Największą dynamikę wykazują trzy parametry odnoszące się do: 1) dostępności pokoi hotelowych w konkretnym obiekcie na dany termin (zmienność danych w czasie rzeczywistym), 2) poziomu deklarowanych cen za nocleg w danym obiekcie (zmienność nawet w czasie rzeczywistym lub dziennym) oraz 3) ogólna liczba hoteli według wykorzystanych do analiz przedziałów cenowych (niejednokrotnie zmienność dzienna). W zależności od daty (a niekiedy nawet godziny) generowania danych ceny deklaratywne za nocleg ulegają zmianom - pokazują się także na bieżąco promocje i zniżki obowiązujące w momencie przeglądania strony hotelu, co ma wpływ na fluktuacje liczebności obiektów według danego kryterium. Najważniejszy jest jednak fakt, że osoba (turysta) chcąca zarezerwować wybrany pokój w konkretnym terminie (np. 28-30.08.2017 r.) za pomoca portalu rezerwacyjnego (pełniącego funkcję pośrednika) ma pewność, że cena, na którą zawarł umowę, będzie stała, taka jak w dniu zakupu (lub zarezerwowania pokoju), zgodnie $\mathrm{z}$ regulaminem danego portalu (https://www.hrs. com/web3/showCmsPage.do?clientId=cGxfX05FWF Q-\&cid=63-4\&pageId=standard-02217). Dla klienta jest to niezwykle funkcjonalne i praktyczne rozwiązanie. Jednak z punktu widzenia użyteczności naukowej taki rodzaj danych ulega zbyt dużej fluktuacji w krótkiej jednostce czasu (godzina, dzień, tydzień), co może zaburzać prawidłowe formułowanie uogólnień dotyczących analizowanego zjawiska.

Próba oceny wielkości udostępnionych w portalach rezerwacyjnych zasobów bazy hotelowej (ogółem) w objętych badaniem metropoliach, wymaga zwrócenia uwagi na pojawiające się w statystykach rozbieżności między oficjalnymi danymi pochodzącymi z Głównego Urzędu Statystycznego a informacjami prezentowanymi w portalach poszczególnych miast (tab. 3). To zaś może prowadzić do utrudnień w interpretacji zjawiska. Zróżnicowania te w przypadku kolejnych serwisów mieszczą się w przedziałach od około $109 \%$ do $123 \%$ dla portalu booking.com, 
Tab. 3. Zróżnicowanie wielkości oraz jakości atrybutów bazy noclegowej według danych oficjalnych GUS i hotelowych portali rezerwacyjnych - synteza według stanu na 2017 r

\begin{tabular}{|c|c|c|c|c|c|c|c|c|c|c|c|c|c|c|c|c|c|c|c|c|c|c|c|c|c|c|c|}
\hline \multirow{3}{*}{\multicolumn{3}{|c|}{ Kryteria oceny }} & \multicolumn{5}{|c|}{ Wrocław } & \multicolumn{5}{|c|}{ Poznań } & \multicolumn{5}{|c|}{ Łódź } & \multicolumn{5}{|c|}{ Kraków } & \multicolumn{5}{|c|}{ Warszawa } \\
\hline & & & \multirow{2}{*}{$\begin{array}{l}\text { dane } \\
\text { GUS }\end{array}$} & \multicolumn{4}{|c|}{ portal $^{\mathrm{a}}$} & \multirow{2}{*}{$\begin{array}{l}\text { dane } \\
\text { GUS }\end{array}$} & \multicolumn{4}{|c|}{ portal $^{\text {a }}$} & \multirow{2}{*}{$\begin{array}{l}\text { dane } \\
\text { GUS }\end{array}$} & \multicolumn{4}{|c|}{ portal $^{\mathrm{a}}$} & \multirow{2}{*}{$\begin{array}{l}\text { dane } \\
\text { GUS }\end{array}$} & \multicolumn{4}{|c|}{ portal $^{\mathrm{a}}$} & \multirow{2}{*}{$\begin{array}{l}\text { dane } \\
\text { GUS }\end{array}$} & \multicolumn{4}{|c|}{ portal $^{\text {a }}$} \\
\hline & & & & 1 & 2 & 3 & 4 & & 1 & 2 & 3 & 4 & & 1 & 2 & 3 & 4 & & 1 & 2 & 3 & 4 & & 1 & 2 & 3 & 4 \\
\hline \multicolumn{3}{|c|}{ Liczba obiektów hotelowych (ogółem) } & 47 & 58 & 53 & 50 & 53 & 57 & 66 & 50 & 40 & 62 & 31 & 36 & 49 & 29 & 53 & 150 & 152 & 83 & 121 & 144 & 86 & 94 & 95 & 69 & 79 \\
\hline \multicolumn{3}{|c|}{ Liczba obiektów z sieci hotelowych } & b.d. & 13 & 13 & 13 & 13 & b.d. & 13 & 11 & 9 & 10 & b.d. & 10 & 8 & 7 & 10 & b.d. & 26 & 22 & 27 & 30 & b.d. & 38 & 29 & 30 & 32 \\
\hline \multirow{6}{*}{\multicolumn{2}{|c|}{$\begin{array}{l}\text { Kategorie hoteli } \\
\text { według liczby } \\
\text { gwiazdek }\left(^{*}\right)\end{array}$}} & 7 & 7 & 6 & 7 & 7 & 3 & 3 & 4 & 3 & 3 & 0 & 0 & 0 & 1 & 0 & 10 & 10 & 7 & 11 & 9 & 12 & 12 & 9 & 12 & 10 & 10 \\
\hline & & 10 & 13 & 20 & 10 & 10 & 15 & 15 & 12 & 14 & 16 & 6 & 5 & 9 & 10 & 8 & 39 & 41 & 24 & 39 & 41 & 16 & 17 & 24 & 15 & 17 & 17 \\
\hline & & 22 & 29 & 24 & 27 & 29 & 29 & 34 & 23 & 19 & 31 & 14 & 16 & 17 & 13 & 18 & 77 & 83 & 43 & 65 & 83 & 34 & 39 & 37 & 32 & 28 & 28 \\
\hline & & 4 & 4 & 3 & 5 & 5 & 9 & 11 & 10 & 4 & 11 & 9 & 8 & 9 & 4 & 11 & 16 & 9 & 7 & 5 & 8 & 17 & 16 & 20 & 6 & 19 & 19 \\
\hline & & 4 & 3 & 0 & 1 & 2 & 1 & 0 & 0 & 0 & 0 & 2 & 2 & 1 & 1 & 1 & 6 & 3 & 1 & 1 & 1 & 6 & 5 & 0 & 4 & 3 & 3 \\
\hline & & 0 & 2 & 0 & 0 & 0 & 0 & 3 & 1 & 0 & 1 & 0 & 5 & 13 & 0 & 15 & 2 & 6 & 1 & 0 & 2 & 1 & 5 & 5 & 0 & 2 & 2 \\
\hline \multirow{4}{*}{\multicolumn{2}{|c|}{$\begin{array}{l}\text { Liczba hoteli według } \\
\text { przedziału cenowego } \\
(\text { w PLN) })^{\mathrm{b}}\end{array}$}} & b.d. & 7 & 25 & 10 & 17 & b.d. & 18 & 13 & 11 & 27 & b.d. & 3 & 29 & 8 & 16 & b.d. & 32 & 11 & 10 & 24 & b.d. & 0 & 10 & 8 & 23 & 23 \\
\hline & & b.d. & 36 & 13 & 33 & 32 & b.d. & 22 & 31 & 26 & 34 & b.d. & 16 & 17 & 17 & 30 & b.d. & 63 & 28 & 56 & 89 & b.d. & 13 & 54 & 34 & 30 & 30 \\
\hline & & b.d. & 13 & 13 & 6 & 3 & b.d. & 15 & 1 & 3 & 1 & b.d. & 5 & 2 & 2 & 4 & b.d. & 41 & 30 & 37 & 23 & b.d. & 35 & 17 & 13 & 15 & 15 \\
\hline & & b.d. & 2 & 2 & 1 & 1 & b.d. & 11 & 5 & 0 & 0 & b.d. & 12 & 1 & 2 & 3 & b.d. & 16 & 14 & 18 & 8 & b.d. & 46 & 14 & 14 & 11 & 11 \\
\hline \multirow{4}{*}{$\begin{array}{l}\text { Rozpiętość } \\
\text { cenowa } \\
\text { (w PLN) } \\
\text { między } \\
\text { maksymalną } \\
\text { a minimalną } \\
\text { ceną ofert }^{c}\end{array}$} & \multirow{2}{*}{$\begin{array}{l}\text { b.d. } \\
\text { b.d. }\end{array}$} & 211 & 159 & 168 & 88 & b.d. & 192 & 198 & 232 & 206,4 & b.d. & 140 & 80 & 171 & 80 & b.d. & 180 & 187,2 & 198 & 169,2 & b.d. & 198 & 115 & 260 & 129 & 260 & 129 \\
\hline & & 2000 & 576 & 1398 & 1012 & b.d. & 1980 & 928,8 & 1900 & 816 & b.d. & 856 & 400 & 895 & 396 & b.d. & 2900 & 2473,9 & 2419 & 2610 & b.d. & 2365 & 888 & 3240 & 2057,4 & 3240 & 2057,4 \\
\hline & \multirow{2}{*}{$\begin{array}{l}\text { b.d. } \\
\text { b.d. }\end{array}$} & 180 & 271 & 185 & 88 & b.d. & 240 & 220 & 325 & 280 & b.d. & 140 & 80 & 178 & 88 & b.d. & 178 & 178,2 & 200 & 178,2 & b.d. & 220 & 95 & 304 & 150 & 304 & 150 \\
\hline & & 2000 & 499 & 3385 & 666 & b.d. & 1718 & 1222 & 2142 & 763 & b.d. & 817 & 500 & 806 & 376 & b.d. & 2415 & 3550 & 3550 & 1948 & b.d. & 3752 & 2376 & 3821 & 1690 & 3821 & 1690 \\
\hline & & b.d. & 13 & 19 & 13 & 13 & b.d. & 20 & 5 & 8 & 9 & b.d. & 7 & 7 & 5 & 3 & b.d. & 24 & 19 & 31 & 29 & b.d. & 8 & 5 & 4 & 2 & 2 \\
\hline & & b.d. & 9 & 8 & 8 & 9 & b.d. & 10 & 10 & 10 & 9 & b.d. & 5 & 6 & 1 & 10 & b.d. & 37 & 17 & 25 & 29 & b.d. & 12 & 12 & 12 & 1 & 1 \\
\hline Lokalizacia ob & & b.d. & 8 & 4 & 9 & 9 & b.d. & 9 & 2 & 4 & 6 & b.d. & 4 & 15 & 6 & 8 & b.d. & 23 & 10 & 20 & 25 & b.d. & 13 & 6 & 8 & 5 & 5 \\
\hline & & b.d. & 6 & 1 & 2 & 1 & b.d. & 3 & 4 & 1 & 1 & b.d. & 2 & 5 & 6 & 10 & b.d. & 9 & 8 & 8 & 7 & b.d. & 4 & 8 & 6 & 11 & 11 \\
\hline & & b.d. & 13 & 11 & 12 & 12 & b.d. & 16 & 17 & 12 & 21 & b.d. & 7 & 9 & 4 & 13 & b.d. & 40 & 16 & 27 & 33 & b.d. & 15 & 10 & 8 & 24 & 24 \\
\hline & & b.d. & 9 & 10 & 6 & 9 & b.d. & 8 & 12 & 5 & 16 & b.d. & 11 & 7 & 7 & 9 & b.d. & 19 & 13 & 10 & 21 & b.d. & 42 & 54 & 31 & 36 & 36 \\
\hline
\end{tabular}

Objaśnienia:

a Kolejnym numerom odpowiadają portale rezerwacyjne: 1 - booking.com; 2 - hrs.com; 3 - hotels.com; 4 - hotel.info; b.d. - brak danych.

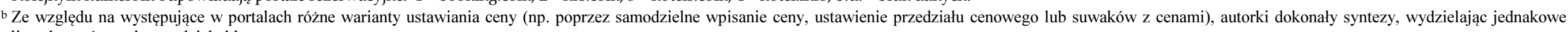
i możliwe do porównania przedziały klasowe.

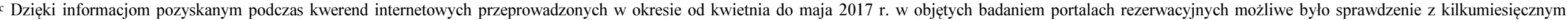

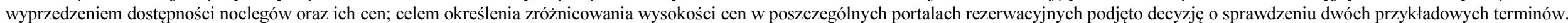

Źródło: opracowanie własne na podstawie danych GUS (2017) oraz kwerendy internetowej najpopularniejszych hotelowych portali rezerwacyjnych w Polsce (2017). 
55-168\% dla hrs.com, 70-106\% dla hotels.com czy 92-171\% dla hotel.info. Oznacza to, że liczba hoteli w konkretnych miastach udostępniających swoje oferty, jest różna, a niejednokrotnie znacznie zawyżona w stosunku do oficjalnego źródła. Przykładem są dane dla:

- Wrocławia - różnice wahają się od 50 (wymienionych w portalu hotels.com) do 58 hoteli (booking.com), podczas gdy do GUS zgłoszono 47 obiektów;

- Łodzi - od 29 (hotels.com) do 53 hoteli (hotel.info) w odniesieniu do 31 obiektów zgłoszonych do GUS.

Zauważalny jest też odwrotny trend. Najlepiej widać to na przykładzie Krakowa, gdzie według oficjalnych statystyk GUS (stan na 2017 r.) znajduje się 150 obiektów hotelowych zlokalizowanych na terenie miasta. Tymczasem liczba hoteli oferowanych w trzech spośród analizowanych portali rezerwacyjnych jest zdecydowanie mniejsza (tab. 3). Waha się w przedziale od 83 (portal hrs.com) do 144 obiektów (hotel.info), co pokazuje rozbieżność danych (w stosunku do oficjalnych statystyk) na poziomie od 55\% do 96\%. Zdaniem autorek artykułu taki stan rzeczy należy tłumaczyć faktem, że hotelarz jest jedynie dostawcą usługi i ponosi koszty związane z prowizją za każdą dokonaną za pomocą pośrednika (tj. portalu) rezerwację. W przypadku portali rezerwacyjnych prowizja kształtuje się w granicach od $12 \%$ do $30 \%$ ceny usługi (ANTONOWICZ 2018). To zaś ma przełożenie na poziom wykorzystywania przez hotelarzy narzędzi e-marketingu (tu portali rezerwacyjnych) do promocji i dystrybucji swojej oferty. Problem wysokości prowizji dotyczyć będzie zwłaszcza małych, rodzinnych obiektów lub nisko skategoryzowanych, o nieugruntowanej pozycji na rynku hotelarskim, albo nienależących do sieci i łańcuchów hotelowych.

Zdecydowanie za najbardziej użyteczną naukowo informację, przekazywaną w portalach rezerwacyjnych wszystkich metropolii, można uznać lokalizację obiektu noclegowego $\mathrm{z}$ określeniem jego położenia względem centrum miasta (tab. 3). Zdaniem autorek artykułu ten rodzaj danych po dokonaniu stosownych analiz można przedstawić w formie zasięgów przestrzennych lokalizacji hoteli poprzez wyznaczenie ekwidystant. $W$ tej sytuacji pojawia się ponownie problem dokładnej liczebności obiektów leżących w zasięgu każdego z buforów miasta, w zależności od badanego portalu. Niemniej wydaje się, że analiza chociażby rodzaju obiektów hotelowych pozwala na prowadzenie dyskusji dotyczącej potwierdzenia koncepcji renty gruntowej w dużych miastach.

Przywołane w pracy przykłady pokazują, że wraz ze zwiększającą się odległością od centrum miasta wzrasta ogólna liczba obiektów małych i tanich, w tym posiadających niewielką liczbę gwiazdek. Z kolei w ścisłym centrum i jego najbliższej okolicy (maksymalnie do 1,5 km) znajdują się obiekty sieciowe głównych marek międzynarodowych (m.in. Mercure, Novotel czy Holiday Inn) oraz krajowych (np. Hotele Diament, Gromada czy Focus Hotels). Szczególna sytuacja zachodzi na obszarze Warszawy. Najprawdopodobniej wynika to ze stołecznej funkcji tej metropolii oraz lokalizacji na jej obszarze największego w Polsce portu lotniczego im. Fryderyka Chopina. Dogłębna analiza danych z poszczególnych portali dotyczących hoteli w Warszawie, skonfrontowana $z$ ich rzeczywistą lokalizacją w przestrzeni miasta, sprawia, że poziom zagęszczenia obiektów hotelowych skupia się w południowej części Warszawy. W centralnej zaś oprócz pojedynczych hoteli różnych kategorii (np. dwugwiazdkowy Hotel Ibis Warszawa Centrum, trzygwiazdkowy Campanille, czterogwiazdkowy Golden Tulip) dominują ekskluzywne apartamenty lub tzw. hotele apartamentowe.

\section{WNIOSKI}

Portale rezerwacyjne stanowią nie tylko element współczesnej promocji obiektów noclegowych (w tym hoteli), ale stają się ważnym narzędziem e-marketingu dla:

- producentów usług noclegowych, pozwalając na znaczne rozszerzenie zasięgu rynkowego firmy (w ujęciu przestrzennym) i wykorzystanie nowoczesnych kanałów dystrybucji poprzez sprzedaż on-line; z drugiej strony umożliwiając dotarcie do nowych segmentów rynku, tj. klientów, którzy z chęcią korzystają ze zdobyczy współczesnej technologii (Internetu) tuż przed wyruszeniem w podróż turystyczną;

- konsumenta (turysty), ułatwiając mu proces poszukiwania obiektu noclegowego i skracając czas potrzebny na znalezienie noclegu; wystarczy sprecyzować swoje wymagania, wpisując w serwisie miejscowość, datę i dodatkowe cechy, a po chwili ukazują się oferty obiektów najbardziej odpowiadających wyznaczonym kryteriom, ponieważ w jednym miejscu klient otrzymuje ofertę przygotowaną przez różne podmioty (hotelarzy).

Dokonana w pracy waloryzacja dowiodła, że najbardziej popularne hotelowe portale rezerwacyjne w Polsce (booking.com, hrs.com, hotels.com i hotel.info) wykazują się relatywnie wysokim poziomem użyteczności zamieszczonych na nich danych i informacji (współczynniki waloryzacji na poziomie 0,70 i więcej), zwłaszcza z punktu widzenia klientów rynku turystycznego. Wychodząc naprzeciw rosnącym oczekiwaniom i wymaganiom turystów, należy zapewnić im portale odznaczające się praktycznością 
i funkcjonalnością, postrzeganą w trzech aspektach: 1) architektury dostępnych informacji, 2) zawartości merytorycznej i 3) użyteczności dla korzystających $\mathrm{z}$ portalu rezerwacyjnego. $\mathrm{Z}$ tego powodu popularne portale rezerwacyjne umożliwiają konsumentom łatwe i szybkie dotarcie do poszukiwanego obiektu noclegowego, uświadamiając im jednocześnie, że istnieją obiekty o różnym poziomie cen i jakości oferowanych usług, zgromadzone w jednym miejscu.

Informacje prezentowane w portalach rezerwacyjnych, dotyczące stricte obiektów hotelowych, zlokalizowanych $\mathrm{w}$ pięciu polskich metropoliach (Warszawie, Krakowie, Łodzi, Wrocławiu i Poznaniu), podlegają nieustannym zmianom w czasie rzeczywistym. Oznacza to, że porównywanie niektórych danych ilościowych (np. dotyczących liczby obiektów hotelowych i ich kategoryzacji), zaczerpniętych z tych serwisów, jest nieco utrudnione i na potrzeby naukowe wymaga docelowo opracowania jakiejś metody postępowania. Jednak wartością dodaną analizowanych portali jest dostęp do zróżnicowanych danych jakościowych - zarówno na poziomie ogólnym (związanych $\mathrm{z}$ funkcjonalnością serwisu), jak i tych konkretnych, dotyczących bazy noclegowej. W opinii autorek pracy pozwalają one na prowadzenie cząstkowych analiz naukowych. Może tyczyć się to studiów mających na celu określenie potencjalnych trendów i tendencji $\mathrm{w}$ rozwoju hotelarstwa $\mathrm{w}$ poszczególnych miastach. Mowa tu np. o badaniach:

- ze zwróceniem uwagi na podaż marek hotelowych (w tym międzynarodowych i krajowych sieci oraz łańcuchów hotelowych), pojawiających się najczęściej w przestrzeni konkretnych miast;

- dostępności renty gruntowej dla nowych obiektów hotelowych w mieście;

- dostępności cenowej hoteli dla różnych segmentów rynku turystycznego.

Reasumując, zróżnicowanie ilościowe i jakościowe dostępnych w portalach rezerwacyjnych danych, które dotyczą obiektów hotelowych, sprawia, że ich użyteczność (nie tylko marketingowa) jest nieporównywalnie większa aniżeli oficjalnych źródeł GUS (ograniczających się tylko do wielkości i rodzaju bazy noclegowej oraz stopnia jej użyteczności). Zdaniem autorek pracy, mimo kilku mankamentów, należy współcześnie wykorzystywać treści zawarte w portalach do badań naukowych i potraktować je jako ważne źródło uzupełniające oficjalne dane (np. z GUS). Dzieje się tak dlatego, że „aplikacje ${ }^{3}$ UGC pozwalają uzyskać wgląd w szczegółowy opis usług i urządzeń oferowanych przez obiekty noclegowe, podczas gdy oficjalne źródła danych statystycznych udostępniają jedynie mocno zgeneralizowane lub niekompletne dane" (DROZDOWSKA, DUDA-SEIFERT 2016, s. 13).

\section{PRZYPISY}

1 Dla kryteriów o charakterze jakościowym zastosowano skalę od 0 pkt do 4 pkt., gdzie 0 pkt oznacza sformułowanie „bardzo źle”, a 4 pkt. - „,bardzo dobrze”. Z kolei w przypadku kryteriów obiektywnych zastosowano skalę zero-jedynkową, gdzie 0 pkt oznacza "brak", tj, że nie ma zjawiska do oceny, a 1 pkt - ,jest", tzn. że ono istnieje.

${ }^{2}$ Współczynnik waloryzacji $=$ liczba otrzymanych punktów z waloryzacji wszystkich cech danego portalu rezerwacyjnego (N) / max. liczba możliwych punktów do otrzymania $\left(\mathrm{N}_{\max }\right.$.)

${ }^{3}$ Określenie user-generated content (UGC) ma podkreślić, że każdy użytkownik z danej platformy może stać się czynnym uczestnikiem wymiany informacji (Constantinides 2009, cyt. za: DROZDOWSKA, DUDA-SEIFERT 2016, s. 9).

\section{BIBLIOGRAFIA}

ANTONOWICZ W., 2018, Jak odpalić biznes hotelowy w Internecie - sześć kroków, [w:] ABC inwestycji hotelowych. Raport magazy$n u$ "Hotelarz", Polskie Wydawnictwa Specjalistyczne ProMedia, Warszawa, s. 48-50.

BAŃSKI J., 2006, Witryny internetowe jednostek samorzadowych z siedziba w matych miastach - analiza i ocena, "Studia Obszarów Wiejskich", t. 11: Rola matych miast w rozwoju obszarów wiejskich, s. 59-72

BŁASZCZUK W., WiTKOWSKI C., 2006, Hotelarstwo w Polsce. Wybrane zagadnienia, Wyd. Akademickie WSSP im. Wincentego Pola w Lublinie, Lublin.

BONICKA J., ANTONOWICZ W., 2018, Inteligentne, sprofilowane systemy przetwarzania danych, [w:] Economy $\mathcal{E}$ technology $\mathcal{E}$ marketing trends 2018, Wyd. Profitroom, Poznań, s. 34-35.

BRANNBACK M., 1997, Is the internet changing the dominant logic of marketing?, „European Management Journal”, 15, 6, s. 698707.

DROZDOWSKA M., DUDA-SEIFERT M., 2016, Turystyczne portale internetowe - wiarygodne źródło informacji?, ,Turyzm/Tourism”, 26, 2, s. 7-13.

ESCOBAR-RODRÍGUEZ T., CARVAJAL-TRUJILlO E., 2013, An evaluation of Spanish hotel websites: Informational vs. relational strategies, "International Journal of Hospitality Management", 33, s. 228-239.

GUZIK R., 2006, Gminy w Internecie, [w:] B. Domański, W. Jarczewski (red.), Klimat inwestycyjny w województwie małopolskim, Departament Gospodarki i Infrastruktury Urząd Marszałkowski Województwa Małopolskiego, Kraków, s. 75-79.

HYSKI M., BEDNARZAK J., 2012, Funkcje hotelarskie zabytkowych obiektów zamkowych, Wyd. Akademia Wychowania Fizycznego im. Jerzego Kukuczki w Katowicach, Katowice.

KOTLER P., 2002, Marketing. Podręcznik europejski, Polskie Wydawnictwo Ekonomiczne, Warszawa.

LAW R., 2009, Disintermediation of hotel reservations: The perception of different groups of online buyers in Hong Kong, "International Journal of Contemporary Hospitality Management", 21, 6, s. 766-772.

MATCZAK A., 1986, Przyrodnicze podstawy organizacji wypoczynku $w$ strefie podmiejskiej Łodzi, "Acta Universitatis Lodziensis. Turyzm", 2, s. 25-45.

MARCUSSEN C.H., 2008, Trends in European internet distribution - of travel and tourism services. Trends in European internet distribution - of travel and tourism services, http://195.130.87.21: $8080 /$ dspace/handle/123456789/864?mode=full\&submit_si mple=Show+full+item+record; 17.10.2018. 
NOWAKOWSKI M., 2012, Użyteczność oficjalnych serwisów internetowych miast na turniej EURO 2012, „Zeszyty Naukowe Uniwersytetu Szczecińskiego. Studia Informatica", 29, s. 43-56.

PIĄDŁOWSKI K., 2006, Portale internetowe, Centrum Edukacji Bibliotekarskiej, Informacyjnej i Dokumentacyjnej im. Heleny Radlińskiej w Warszawie, Warszawa.

PRAŁAT E., 2011, Badania witryn internetowych polskich gmin, „Zeszyty Naukowe Uniwersytetu Szczecińskiego. Ekonomiczne Problemy Usług", 67, s. 564-571.

PRZYBYLAK D., 2005, Znaczenie marketingu w ustugach turystycznych, [w:] W. Siwiński, R.D. Tauber, E. Mucha-Szajek (red.), Hotelarstwo, rekreacja, turystyka. Kierunki przemian w świecie postindustrialnym, Wyd. WSGiH w Poznaniu, Poznań, s. 256266.

RUNGE J., 2006, Metody badań w geografii spoteczno-ekonomicznej - elementy metodologii, wybrane narzędzia badawcze, Wydawnictwo Uniwersytetu Śląskiego, Katowice.

SHELDON P.J., 1997, Tourism information technology, CAB International, Wallingfort.

STANGL B., INVERSINI A., SCHEGG R., 2016, Hotels' Dependency on online intermediaries and their chosen distribution channel portfolios: Three country insights, „International Journal of Hospitality Management", 52, s. 87-96.
Ustawa z dnia 29.08.1997 roku o ustugach hotelarskich oraz ustugach pilotów wycieczek i przewodników, DzU z 2018 r., poz. 650.

WERTHNER H., RICCI F., 2004, E-commerce and tourism, "Communitation of the $\mathrm{ACM}^{\prime \prime}, 47,12$, s. 101-105.

WERTHNER H., KLEIN S., 1999, Information technology and tourism, Springer Verlag Vien, Vien.

WiTKOWSKI Cz., 2007, Hotelarstwo, cz. 1: Podstawy hotelarstwa, Wyd. Almamer, Warszawa.

WOJCIECHOWSKA J., 2003, Analiza i ocena zagospodarowania turystycznego, [w:] S. Liszewski (red.), Możliwości i kierunki rozwoju turystyki w Dolinie Odry, Katedra Geografii Miast i Turyzmu UŁ, Łódzkie Towarzystwo Naukowe, Łódź, s. 136-156.

http:/ / www.e-hotelarz.pl/mht/?p=29196.

https://pl.hotels.com/.

https://www.booking.com/.

https://www.e-hotelarz.pl/mht/?p=14002.

https://www.hotel.info/.

https://www.hrs.com/.

https:// poradnikprzedsiebiorcy.pl/-marketing-internetowy0.

Artykuł wpłyną: 31 sierpnia $2018 \mathrm{r}$. Zaakceptowano do druku: 29 października 2018 r. 